\title{
KNOWLEDGE AND PRACTICES ON HIV/AIDS AMONG INJECTING DRUG USERS
}

\author{
Subhash Prasad \\ Department of Health \&Physical Education, TU, Thakur Ram Multiple Campus, Birganj, Nepal \\ Email:subhashpd75@gmail.com
}

\begin{abstract}
Injecting drug use is the main route of transmission of HIV/AIDS. Injecting Drug Users (IDUs) are one of the high risk groups of this infection. This paper describes the knowledge and practice of HIV in injecting drug users based on quantitative data collected from 154 IDUs by interview schedule. It is concluded that the knowledge about HIV/AIDS amongst the injecting drug users is not a problem. The key problem is sharing used syringe by some users to take drugs to fulfill their urgent compulsion. The gap between knowledge and practice causes them to the vulnerability of the problem.
\end{abstract}

\section{Keywords}

HIV; AIDS; IDUs; new sterilized syringe; use of new syringe practice

\section{Introduction}

Generally, mankind has been suffering from various types of diseases. Out of those most are curable and some of them are incurable. Human Immunodeficiency Virus/Acquired Immunodeficiency Syndrome (HIV/AIDS) is an incurable disease. Mankind has not fully been released from different fatal diseases .HIV/AIDS is one of them. The communicable HIV/AIDS has raised the suffering to the high extent and threatened the very existence of mankind. There is no permanent cure for this disease as so far. Drugs so far developed help only increase the immune efficiency, but it is not affordable to common people. So, it is beyond the reach of general people. That is why, the prevention measures are the main option to curb the rapid spreading of this deadly disease.

Acquired Immunodeficiency Syndrome (AIDS) is a fatal illness caused by a retrovirus known as the Human Immunodeficiency Virus (HIV) which break down the body's immune system, leaving the victim vulnerable to a host of life-threatening opportunistic infections, neurological disorders, or unusual malignancies. AIDS is the last stage of HIV infection. HIV destroys immunity of the body leaving the victim highly susceptible to simple infectious diseases like Tuberculosis, Influenza etc., which then become the direct cause of death (Park, 1998). The injecting 
drug user is a person who injects various drugs in muscles or in veins for intoxication purposes. The five stages of substance abuse in youth are curiosity, experimentation, regular use, psychological or physical dependency using drugs to feel 'normal' (Ray, 1998).

In Nepal, the first-ever AIDS case was reported in 1988. Ever since, the nature of the HIV epidemic in the country has gradually evolved from being a "low-prevalence" to "concentrated" epidemic. HIV prevalence among general population is 0.7 percent. There are many reasons of transmission of HIV such as injecting drug users, female sex workers, migrants etc. Within the general population, identified high-risk sub-groups are contributing to the spread of HIV (WHO, 2006). One of the research (NCASC, 2012) says that over 8 o per cent of the HIV infections are transmitted through heterosexual practices, people who inject drugs, men who are in guy relationship and female sex workers (FSWs). These are the key populations at higher risk spreading this epidemic.

Injecting drug use can lead to the exponential growth of HIV transmission in a community. It is estimated that there are approximately 23.2 million people who use injecting drugs in over 155 countries worldwide. Approximately 78 percent of the people who use injecting drugs live in transitional and developing countries, making it a significant barrier in accessing adequate HIV prevention, treatment, care and support services. South -East Asian Region (SEAR) has the second highest burden of HIV in the world having about 5.6 million drug injectors. HIV infection in this population is largely uncontrolled. Six countries - India Thailand, Myanmar, Indonesia, Bangladesh and Nepal account for the majority of the regional burden of HIV among injectors. HIV prevalence among injecting drug users ranges from 7 percent to 52 percent in these countries (WHO, 2008).

According to FHI (2009), the number of
IDUs found in Nepal stands between 17,0oo and 24,00o with an estimated prevalence of HIV around 23 percent, a decrease from 32.7 percent in 2005. These figures translate to upwards of 4,800 injecting drug users in Nepal living with HIV. The majorities are found in Kathmandu valley and the Highway districts including Pokhara (FHI, 2009). There were 12,033 HIV positive cases in Nepal, out of which 2,358 HIV injecting drug users were adolescents and young adults age $10-29$ years. Of these 2,313 were male and remaining 45 were female (NCASC, 2008).

Injecting drug use is the main route of transmission for approximately $10 \%$ of HIV infections globally and 30\% of infections outside sub Saharan Africa. Preventing HIV transmission through injecting drug use is one of the main challenges to reduce the burden of HIV (UNAIDS 2012). New ways of taking drugs, such as by intravenous injection, have led to breakdown in the equilibrium which societies had maintained for centuries. Traditional, social and cultural controls on human behaviour have been weakened or destroyed.

Rautahat, one of the districts of middle-east terai region of Nepal, is one of the high risk districts in transmission of HIV and AIDS. A size estimation survey shows maximum 645 to minimum 564 IDUs are actively involved (NCASC, 2012). Out of them 512 IDUs are still in contact with Arunoday Youth Club and three IDUs have died, 73 people have been suffering. District AIDS Coordination Committee-Rautahat claims about 107 people are suffering from HIV/AIDS. Realizing the situation, more than 10 organizations have been working in the field of HIV prevention focusing defined sub-group. Out of them AYC has been working focusing on IDUs.

Among the high-risk groups, Injecting Drug Users (IDUs) likewise the sex worker groups are one of the identified target groups to be covered by prevention program so that multi donor and implementing agencies are could 
reach among them throughout comprehensive program. The country's vulnerability to HIV and AIDS is further exacerbated by Poverty, gender discrimination, geographic and ethnic diversity, its' land locked location between India and china, poverty, inequality and underdevelopment, political instability, varied levels of knowledge about his/her transmission among most-at-risk groups and young people, insufficient risk reduction behaviors among most-at-risk groups and young people

The mode of taking drug mostly converts the way of injecting. The unsafe behaviour of infected needle and syringe exchange causes the HIV infection. Some IDUs are involved in sex industry. Their unsafe needle exchange and sexual behaviour is not only leading them to the darkness of HIV/AIDS but also the entire society is under the threat of its epidemic. Thus, the transmission of HIV is rapidly growing day- by- day. That is why, safe behavioural health education is a priority need of the whole community to prevent HIV/ AIDS.

\section{Methods}

This paper is based on the study conducted in Routahat district in 2013. Respondents of the study were the Injecting drug users. Out of 512 IDUs, 154 were selected by purposive sampling method. The interview schedule was main tool for data collection. The data has been analysed quantitatively.

\section{Results and discussion}

The results have been presented and discussed under the following headings:

\section{Sources of knowledge on HIV/AIDS}

Human knowledge on particular things and subjects reflect their perception and behaviour. Proper knowledge makes it possible to know the significance of the changes. It is perceived that only the knowledge could lead the person to the right direction.
The study revealed that all IDUs know about HIV and AIDS through different sources. Access to information concerning HIV/AIDS of the injecting drug users is determined by a number of factors like exposure to different TV channels, contacts with social/health workers, health service institutions, sharing and discussions with peers/friends etc. The table 1 shows the sources of knowledge on HIV and AIDS:

Table 1: Sources of knowledge on HIV/AIDS

\begin{tabular}{|l|c|c|}
\hline $\begin{array}{l}\text { Sources of } \\
\text { knowledge }\end{array}$ & Number & Percentage \\
\hline Peers & 93 & 60 \\
\hline $\begin{array}{l}\text { Social/Health/ } \\
\text { Volunteers }\end{array}$ & 146 & 95 \\
\hline $\begin{array}{l}\text { TV/Radio/ } \\
\text { Papers/ } \\
\text { Magazines }\end{array}$ & 137 & 89 \\
\hline
\end{tabular}

(Note: Multiple Responses)

Table 1 shows that the majority of the respondents (95 percent) have got knowledge about HIV/AIDS through social/health workers and volunteers. Similarly, 6o percent got from their peers whereas 89 percent have got through publication/TV/Radio. Hence, the table reveals that the intervention program launched by different organizations seem effective, because majority of respondents were reported that they got the information from Peers and Social/Health workers and volunteers.

\section{Knowledge about modes of HIV transmission}

The IDUs population group accounts for the largest proportion of HIV-positive people amongst the country. It has disclosed that common use of syringe while taking drug is also one of the major route through which HIV has spreaded into the Nepalese population (NCASC, 2012). Table 2 clarifies the knowledge on transmitting modes: 
Table 2: Knowledge on modes of transmission of HIV/AIDS

\begin{tabular}{|l|c|c|}
\hline $\begin{array}{l}\text { Mode of } \\
\text { transmission }\end{array}$ & Number & Percentage \\
\hline Using used needles & 148 & 96 \\
\hline $\begin{array}{l}\text { From blood } \\
\text { transfusion }\end{array}$ & 104 & 68 \\
\hline $\begin{array}{l}\text { Sexual intercourse } \\
\text { with infected people }\end{array}$ & 144 & 94 \\
\hline $\begin{array}{l}\text { Infected mother to } \\
\text { her baby }\end{array}$ & 103 & 67 \\
\hline
\end{tabular}

(Note: Multiple Responses)

Table 2 shows that 96 percent know about used needles responsible for the transmission of HIV/AIDS. It also reveals that, 94 percent know about sexual intercourse with infected people, 68 percent know about blood transfusion and 67 percent know about infected mother to their baby. The data shows wider variation on knowledge of transmission of HIV.

\section{Knowledge on preventive measure}

HIV/AIDS is one of the incurable fatal diseases which is difficult to cure. So, it is said that "prevention is always better than cure" and since there is no cure, the only way to keep one safe is to apply preventive measures. So, there should be proper education regarding HIV/ AIDS and the preventive measures to control its spread.

Table 3: Knowledge on preventive measures of HIV/AIDS

\begin{tabular}{|l|c|c|}
\hline $\begin{array}{l}\text { Preventive } \\
\text { methods }\end{array}$ & Number & Percentage \\
\hline Using condom & 151 & 98 \\
\hline $\begin{array}{l}\text { Avoiding used } \\
\text { syringe and } \\
\text { taking new }\end{array}$ & 149 & 97 \\
\hline $\begin{array}{l}\text { Avoiding sex } \\
\text { with sex workers }\end{array}$ & 97 & 63 \\
\hline
\end{tabular}

(Note: Multiple Responses)
In the table 3, knowledge on preventive measures of HIV/AIDS has been presented. Data reveal that 98 percent were using condom to prevent the HIV/AIDS, 97 percent avoided used syringe and took new one. Similarly, 63 percent were avoiding sex with sex workers to prevent HIV infection. The majority of the respondents were found equipped with significantly high level of knowledge on different methods of prevention. So it seemed to be effective and successful to inject the preventive knowledge by the different intervention programs which are launched by various governmental and non-governmental organizations.

Sources of knowledge about safely injecting behaviours

The mode of taking drug through syringe and its common use causes the transmission of HIV from one to another, if the used syringe is infected. So, among these injecting drug users, there should be proper knowledge and practice of safe behaviour. Otherwise, it may play the vital transmission role to spread HIV among the injecting drug users and their sex partners. Table 4 demonstrates sources of information of using new sterilized syringe:

Table 4: Sources of knowledge about new sterilized syringe

\begin{tabular}{|l|c|c|}
\hline $\begin{array}{l}\text { Sources of } \\
\text { knowledge }\end{array}$ & Number & Percentage \\
\hline Peers & 46 & 30 \\
\hline $\begin{array}{l}\text { Social/Health/ } \\
\text { Volunteers }\end{array}$ & 152 & 99 \\
\hline $\begin{array}{l}\text { TV/Radio/Papers/ } \\
\text { Magazines }\end{array}$ & 64 & 42 \\
\hline
\end{tabular}

(Note: Multiple Responses)

Table 4 shows that 99 percent respondents got knowledge about new sterilized syringe through social/health workers/volunteers. Similarly, 30 percent and 42 percent of respondents were informed through their peers and media i.e. Radio/TV and print. 
It reveals that majority of the sources of knowledge is social/ health workers than print or electronic media and peer group.

\section{Common syringe sharing practice}

Common syringe sharing practice is a main factor to transmit HIV infection in IDUs. Table 5 demonstrates their common syringe sharing practice:

Table 5: Common syringe sharing practice

\begin{tabular}{|l|c|c|}
\hline $\begin{array}{l}\text { Common syringe } \\
\text { sharing practice }\end{array}$ & Nos. & Percentage \\
\hline $\begin{array}{l}\text { Common syringe } \\
\text { users in previous day }\end{array}$ & 139 & 90 \\
\hline $\begin{array}{l}\text { Common syringe } \\
\text { users before last 12 } \\
\text { months }\end{array}$ & 56 & 36 \\
\hline $\begin{array}{l}\text { Common syringe } \\
\text { users with sex } \\
\text { partner in past one } \\
\text { month }\end{array}$ & 4 & 3 \\
\hline $\begin{array}{l}\text { Common syringe } \\
\text { users in past one } \\
\text { month }\end{array}$ & 14 & 9 \\
\hline
\end{tabular}

(Note: Multiple Responses)

Table 5 reveals that 139 out of 154 respondents used to have practice of using common syringe in previous day, 56 respondents used common syringe 12 months ago whereas, 14 respondents used common syringe one month ago. Similarly, 4 respondents shared common syringe with sex partner one month ago. It reveals that majority of the IDUs used to have practice of common syringe while drugs taking through injecting. Trends of using common syringe are minimized in the past one month. Additionally it was also found that IDUs share syringe with usual sex partners.

\section{Gap between knowledge and practice of} new unused sterilized syringe

The knowledge which is acquired by human being does not always reflect in the practices. There might be difference between knowledge and practice because practices are always conditional and affected by the external situation. The stigma for injecting drug users in the society is one of the affecting factors on their practice of using new syringe. Sometimes, they could not go to take new syringe when they are in need. They do not want to be exposed in front of anyone because of the stigma in the society.

It was found that the knowledge about new unused sterilized syringe is fully known among all the respondents. Although the majority of the respondents about 97 percent know about new unused sterilized syringe that prevents HIV infection, still 91 percent of the respondents are practicing it or 9 percent respondents don't use new unused sterilized syringe sometimes. According to the IDUs, they have not problem of knowing about the use of new syringe as preventive measures from HIV infection, and they don't have new syringe available to take the drug is a main problem.

\section{Conclusion}

It may be concluded that injecting drug users have sufficient knowledge about mode of transmission and use of unused new syringe as a preventive measure of HIV/AIDS. Despite having sufficient knowledge about HIV/AIDS, some of the IDUs sometimes get obliged to share used syringes to take drugs. The gap between knowledge and practice causes them to the vulnerability of the problem. The problems that exist between knowledge and practice were: not easy availability/accessibility of new syringes and condoms, social stigma and fragile condition of IDUs. The injecting drug user needs to have information, confidence and skill to discuss the problem and to make changes in their needle sharing and sexual behavior. So, the better program coverage, peer education as well as outreach intervention should be continued and promoted among the drugs users for the prevention and care of HIV/ AIDS. 


\section{References}

FHI (2009). Epidemiological profile of a most-atrisk population in Nepal: IDUs. Kathmandu: Author.

NCASC ( 2008). Cumulative HIV and AIDS situation of Nepal. Kathmandu: Author.

NCASC ( 2012). National estimates of HIV infections in Nepal, 2011. Kathmandu: Author.

NCASC (2012). Mapping and size estimation of MARPs in Nepal. Kathmandu: Author.
Park, K. (1998). Park's Textbook of Preventive and Social Medicine (15th ed.). Jabalpur, India: M/S Banarsidas Bhanot.

Ray, R. (1998). Drug demand reduction report. New Delhi, India: UNDCP.

UNAIDS (2012). Global AIDS response progress report. Geneva: Author.

WHO (2006). HIV/AIDS Strategic framework for south east reign. Geneva: Author.

WHO (2008). Lead empower deliver, injecting drug use and HIV transmission. Geneva: Author.

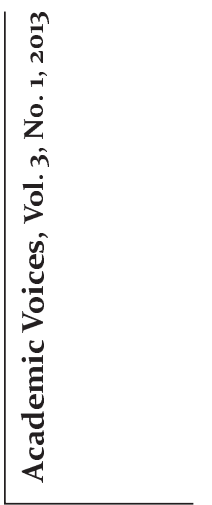

